\title{
Effects of Dietary Rumen-Protected Betaine Supplementation on Performance of Postpartum Dairy Cows and Immunity of Newborn Calves
}

\author{
Beibei Wang ${ }^{1}$, Chong Wang ${ }^{2}$, Ruowei Guan ${ }^{1}$, Kai Shi ${ }^{1}$, Zihai Wei ${ }^{1}$, Jianxin Liu ${ }^{1}(\mathbb{D}$ and \\ Hongyun Liu 1,* (D) \\ 1 College of Animal Sciences, Zhejiang University, Hangzhou 310058, China; 21617083@zju.edu.cn (B.W.); \\ 21617025@zju.edu.cn (R.G.); shik_1992@163.com (K.S.); weizihai365@163.com (Z.W.); liujx@zju.edu.cn (J.L.) \\ 2 College of Animal Sciences and Technology, Zhejiang A \& F University, Hangzhou 311300, China; \\ wangcong992@163.com \\ * Correspondence: hyliu@zju.edu.cn; Tel.: +86-571-88982965
}

Received: 8 March 2019; Accepted: 12 April 2019; Published: 15 April 2019

Simple Summary: Betaine plays an important role in growth, lactation, protein synthesis, and fat metabolism in animals, but there are few studies on transition dairy cows and newborn calves. The aim of the current study was to evaluate the effects of rumen-protected betaine supplementation from four weeks before expected calving to six weeks postpartum regarding the lactation performance and blood metabolites of dairy cows and immunity of newborn calves. The results suggested that betaine supplementation tended to increase fat mobilization of postpartum dairy cows. Furthermore, compared to the control calves, the betaine calves had greater plasma total protein and globulin concentrations, which indicates that the immunity of the betaine calves might have improved.

\begin{abstract}
The objective of this study was to evaluate the effects of rumen-protected betaine supplementation on performance of postpartum dairy cows and immunity of newborn calves. Twenty-four multiparous Holstein dairy cows were randomly divided into the control (CON, $n=12)$ and rumen-protected betaine (BET, $n=12$ ) groups after blocking by parity and milk yield during the previous lactation cycle. The cows were fed a basal total mixed ration diet without BET (CON) or with BET at $20 \mathrm{~g} / \mathrm{d}$ per cow (BET) from four weeks before expected calving to six weeks postpartum. The results showed that betaine supplementation had no effect on dry matter intake and milk yield of the cows. The BET cows tended to increase feed efficiency (energy-corrected milk/dry matter intake) and body weight loss postpartum compared to the CON cows. The plasma $\beta$-hydroxybutyrate concentrations of the BET cows were greater at $d$ seven after calving than those of the CON cows. Moreover, compared to the CON calves, the BET calves had greater plasma total protein and globulin concentrations. The plasma glucose concentrations of the BET calves tended to decrease relative to CON cows. In conclusion, rumen-protected betaine supplementation from four weeks before expected calving tended to increase fat mobilization of postpartum dairy cows, and might improve the immunity of newborn calves.
\end{abstract}

Keywords: betaine; dairy cows; newborn calves; fat mobilization; immunity

\section{Introduction}

During the transition period, dairy cows are in a state of great metabolic stress because of the increased demand for nutrients to maintain fetal growth and milk synthesis. Transition dairy cows tend to have negative energy and amino acid balance after calving, which leads to an increase in fat and protein mobilization in tissues [1,2]. A negative methyl donor balance also likely occurs in transition 
cows because milk is high in methylated compounds [3]. Moreover, the last two months of gestation, where $60 \%$ of the body weight gain before birth occurs [4], is critical for bovine fetal development.

Betaine functions as a methyl donor and an organic osmolyte [2,5], which plays an important role in growth, lactation, protein synthesis, and fat metabolism in animals [6]. Betaine supplementation in the diets of steers increased body weight gain and fat deposition [7]. In lactating dairy cows, feeding betaine improved the milk yield and milk protein $[8,9]$. Supplementing betaine reduced plasma concentrations of non-esterified fatty acids (NEFA) and $\beta$-hydroxybutyrate (BHB) of lactating dairy cows [10], but elevated the concentrations of NEFA and BHB of transition dairy cows to change lipid metabolism [11]. Furthermore, betaine is vital for fetal development [12], and is related to the offspring's weight and immunity [13]. However, due to the fast rumen degradation (approximately $45 \% / \mathrm{h}$ ) of betaine in vivo [14], unprotected betaine cannot be absorbed efficiently. Our previous study showed that dietary rumen-protected betaine supplementation in lactating dairy cows improved lactation performance and fat metabolism [15]. Whether it improves the performance of postpartum dairy cows and the immunity of newborn calves remains unexplored. Therefore, the objectives of the current study were to evaluate the effects of rumen-protected betaine supplementation from four weeks before expected calving to six weeks postpartum on the lactation performance and blood metabolites of dairy cows and immunity of newborn calves.

\section{Materials and Methods}

\subsection{Animals and Treatments}

All the experimental protocols used in this study were approved by the Animal Care Committee of Zhejiang University (Hangzhou, China) (Approval Number: ZJU20160379). Twenty-four multiparous prepartum Holstein dairy cows were selected and divided randomly into the control (CON, $n=12)$ and rumen-protected betaine (BET, $n=12)$ groups after blocking by parity $(2.27, \mathrm{SD}=1.4)$ and milk yield during the previous lactation cycle $(24.9 \mathrm{~kg} / \mathrm{d}, \mathrm{SD}=6.0)$. The cows were fed a basal total mixed ration (TMR) diet (Table 1) without BET (CON) or with BET at $20 \mathrm{~g} / \mathrm{d}$ per cow (BET), according to Zhang et al. (2014) [9] from four weeks before expected calving to six weeks postpartum. The basal diets were formulated based on the NRC (2001) [16]. The cows were fed three times daily at approximately 06:30, 13:30, and 19:30 h, and BET (BET with 30\% purity, Hangzhou King Technology Feed Co., Ltd, Hangzhou, China) was supplemented twice daily in the morning and evening by top-dressing the TMR during feeding. All cows were housed in tie-stall barns and given access to fresh water ad libitum. After parturition, the cows were milked three times daily at approximately 07:00, 14:00, and 20:00 h. Fourteen calves randomly selected (CON calves: $n=7$, BET calves: $n=7$ ) were studied from birth to $24 \mathrm{~h}$. All calves were weighed with a digital scale immediately after birth and were fed fresh colostrum from their dams within $2 \mathrm{~h}$ of birth. The calves were individually housed in hutches, and water was offered ad libitum.

Table 1. Ingredient and chemical composition of the diets fed during the prepartum and postpartum periods.

\begin{tabular}{ccc}
\hline Item & Prepartum & Postpartum \\
\hline \multicolumn{2}{c}{ Ingredient, \% of $\mathrm{DM}^{1}$} \\
\hline Corn flour & 12.41 & 13.39 \\
Steam-flaked corn & 7.15 & 11.93 \\
Soybean meal & 8.61 & 13.68 \\
Bran & 5.30 & - \\
Sodium bicarbonate & 0.40 & 0.72 \\
Calcium hydrophosphate & 0.40 & 0.48 \\
Limestone & 0.60 & 0.66 \\
Fatty acid calcium salts & - & 0.78 \\
Salt & 0.39 & 0.46 \\
\hline
\end{tabular}


Table 1. Cont.

\begin{tabular}{ccc}
\hline Item & Prepartum & Postpartum \\
\hline \multicolumn{2}{c}{ Ingredient, \% of DM ${ }^{1}$} \\
\hline Premix ${ }^{2}$ & 0.37 & 0.44 \\
Mycotoxin binder & 0.05 & 0.07 \\
Active yeast & - & 0.07 \\
Brewer's grains & 7.31 & 4.55 \\
Beet pulp & 6.70 & 9.26 \\
Corn silage & 25.39 & 21.05 \\
Alfalfa hay & 6.78 & 16.86 \\
Oat grass & 18.08 & 5.62 \\
\hline Chemical composition, $\%$ of DM \\
\hline Crude protein & 10.99 & 17.49 \\
Ether extract & 3.27 & 4.31 \\
Crude ash & 7.96 & 7.84 \\
Neutral detergent fiber & 48.48 & 37.08 \\
Acid detergent fiber & 27.57 & 20.78 \\
NEL, Mcal/kg of DM & - & 1.63 \\
Lys: Met & $2.76: 1$ & $3.13: 1$ \\
\hline
\end{tabular}

${ }^{1} \mathrm{DM}=$ dry matter. $^{2}$ Formulated to contain (per kilogram of premix) 220 to $400 \mathrm{KIU}$ of vitamin A, 50 to $100 \mathrm{KIU}$ of vitamin D3, $\geq 2250$ IU of vitamin E, $\geq 40 \mathrm{mg}$ of D-Biotin, $\geq 380 \mathrm{mg}$ of niacinamide, $\geq 40 \mathrm{mg}$ of Beta-carotene, 0.2 to $0.7 \mathrm{~g}$ of $\mathrm{Cu}, 1.0$ to $3.8 \mathrm{~g}$ of $\mathrm{Zn}, 0.8$ to $3.0 \mathrm{~g}$ of Mn, 12.5 to $100 \mathrm{mg}$ of I, 8.0 to $25 \mathrm{mg}$ of Se, 2.5 to $50 \mathrm{of} \mathrm{mg} \mathrm{Co}, 10.0 \%$ to $30.0 \%$ of $\mathrm{Ca}, 10.0 \%$ to $30.0 \%$ of $\mathrm{NaCl}$, and $\geq 1.5 \%$ of total phosphorus.

\subsection{Sample Preparation}

The amounts of feed offered and refused were recorded according to Gu et al. (2018) [17] to determine dry matter intake (DMI). The TMR samples were collected weekly for dry matter (DM, $105^{\circ} \mathrm{C}$ for $5 \mathrm{~h}$ ), crude ash, ether extract (EE), crude protein (CP), and acid detergent fiber (ADF), according to AOAC procedures (method 942.05, 920.39, 988.05, and 973.18, respectively), and neutral detergent fiber (NDF) with sodium sulfite and amylase was analyzed [18]. Body weight (BW) was measured on d 0 and 42 after calving according to Wang et al. (2017) [19].

Milk yield was recorded for two consecutive days each week and milk samples from three consecutive milking were taken each week in the amounts proportional to the yield (4:3:3, composite from each daily milking). The samples were stored at $4{ }^{\circ} \mathrm{C}$ with bronopol tablets (D \& F Control System Inc., San Ramon CA, USA) for later determination of protein, fat, lactose, total solids, and milk urea nitrogen (MUN) using a Combi Foss FT+ instrument (Foss Electric, Hillerød, Denmark). The 3.5\% FCM (Fat-corrected milk) and ECM (Energy-corrected milk) were calculated by the formula [20]: 3.5\% FCM $=($ milk yield, $\mathrm{kg} / \mathrm{d} \times 0.4324)+($ milk fat, $\mathrm{kg} / \mathrm{d} \times 16.216), \mathrm{ECM}=($ milk yield, $\mathrm{kg} / \mathrm{d} \times 0.327)+($ milk fat, $\mathrm{kg} / \mathrm{d} \times 12.95)+($ milk protein, $\mathrm{kg} / \mathrm{d} \times 7.20)$.

Blood samples from the cows were collected from the coccygeal vein in sodium-heparinized tubes at approximately $4 \mathrm{~h}$ after the morning feeding on $-21,-10,0,7,14,28$, and $42 \mathrm{~d}$ relative to calving. Blood samples from the calves were collected via the jugular vein using a sodium-heparinized tube shortly after birth before colostrum feeding and at approximately $24 \mathrm{~h}$ after birth. The samples were centrifuged for $10 \mathrm{~min}$ at $3000 \mathrm{~g}$ at $4{ }^{\circ} \mathrm{C}$ to harvest plasma, which was stored at $-20^{\circ} \mathrm{C}$ until analysis. The plasma samples were analyzed using an Auto Analyzer 7020 instrument (Hitachi High-Technologies Corp., Tokyo, Japan) with colorimetric commercial kits (Ningbo Medical System Biotechnology Co., Ltd., Ningbo, China) for total protein (TP), albumin (ALB), alanine aminotransferase (ALT), aspartate aminotransferase (AST), alkaline phosphatase (ALP), total bilirubin (TBIL), triglyceride (TG), cholesterol (CHOL), glucose (GLU), superoxide dismutase (SOD), NEFA, and BHB. The concentrations of globulin (GLOB) were calculated by the formula [21]: GLOB $(\mathrm{g} / \mathrm{L})=\mathrm{TP}(\mathrm{g} / \mathrm{L})-\mathrm{ALB}(\mathrm{g} / \mathrm{L})$. 


\subsection{Data Analysis}

A randomized block design with repeated measures was used. The DMI, lactation performance, feed efficiency, and blood metabolites of the cows were analyzed with PROC MIXED of SAS 9.2 (SAS Institute Inc., Cary, NC, USA). Treatment, week, treatment $\times$ week, and block were included as the fixed effects in the model, and cow within treatment was used as a random effect. The blood metabolites of the calves were analyzed using the same procedure in SAS 9.2, except sampling hour instead of week was used as the repeated measure. The BW change of the cows, colostrum composition, and calves birth weight were analyzed using PROC MIXED of SAS 9.2 without the repeated statement. All associated interactions were removed from the model. The results are presented as least squares means. Statistical significance was determined at $p \leq 0.05$ and tendencies at $0.05<p \leq 0.10$.

\section{Results and Discussion}

Betaine supplementation had no effect on DMI, milk yield, and composition ( $p>0.1$, Table 2). Monteiro et al. (2017) [11] found that cows supplemented with betaine-containing molasses from $60 \mathrm{~d}$ before expected calving had higher milk yield, whereas no differences were observed in milk yield of cows supplemented with betaine-containing molasses from $24 \mathrm{~d}$ before expected calving, which is consistent with our results. The addition of betaine during the transition period increased the milk yield in a time-dependent manner, which might be related to the functions of betaine as an organic osmolyte to maintain the cell function by stabilizing cellular proteins and promoting proper protein folding [5,22]. The dry period is critical for the renewal and growth of mammary cells [23]. Hence, betaine addition during the far-off period has a positive effect on prepartum mammary growth, which increases the subsequent milk yield. The Lys: Met ratio in the postpartum diets was estimated to be 3.13:1 in our study, which had met the ideal Lys: Met ratio of 3.0:1 for an optimal milk protein content and yield [16,24]. Methyl donors (choline) additional supplementation had no detectable effect on cow performance when the Lys: Met ratio in diets had reached 3.0:1 [25]. This might also be a reason for BET additional supplementation, which has no effect on milk yield and composition.

Compared to CON cows, BET cows tended to increase fat-corrected milk/dry matter intake (FCM/DMI, $p=0.09$ ), energy-corrected milk/dry matter intake (ECM/DMI, $p=0.08$ ), and BW loss postpartum $(p=0.10)$ (Table 2). The plasma BHB concentrations of the BET cows were greater at d seven after calving than those of the CON cows (treatment $\times$ time: $p=0.07$, Table 3 ). The greater number of animals in the study might have increased the statistical significance. The BET cows tended to have greater feed efficiency and BW loss postpartum in our study, coupled with greater concentrations of BHB at d seven after calving, which indicates that the BET cows might have an enhanced fat mobilization in early lactation due to higher milk yield numerically (milk yield was approximately $2.53 \mathrm{~kg} / \mathrm{d}$ higher in BET cows than in CON cows) $[11,26]$.

Table 2. Effects of supplementing cows without rumen-protected betaine (CON) or with rumen-protected betaine (BET) on dry matter intake, lactation performance, and body weight change during the first six weeks of lactation.

\begin{tabular}{ccccccc}
\hline \multirow{2}{*}{ Items } & \multicolumn{2}{c}{ Treatment } & \multirow{2}{*}{ SEM } & \multicolumn{3}{c}{$p$-Value } \\
\cline { 2 - 3 } & CON & BET & & Treat & Week & Treat $\times$ Week \\
\hline DMI, kg/d & 20.33 & 20.21 & 0.76 & 0.92 & $<0.01$ & 0.10 \\
Milk yield, kg/d & 30.44 & 32.97 & 1.68 & 0.31 & $<0.01$ & 0.61 \\
Milk composition & & & & & & \\
Fat, \% & 4.30 & 4.18 & 0.09 & 0.35 & $<0.01$ & 0.44 \\
Protein, \% & 3.23 & 3.13 & 0.06 & 0.30 & $<0.01$ & 0.71 \\
Lactose, \% & 5.00 & 4.94 & 0.04 & 0.28 & 0.00 & 0.50 \\
Total solids, \% & 12.93 & 12.77 & 0.13 & 0.42 & $<0.01$ & 0.93 \\
MUN, mgN/dL & 10.74 & 10.64 & 0.63 & 0.91 & 0.00 & 0.23 \\
3.5\% FCM ${ }^{1}, \mathrm{~kg} / \mathrm{d}$ & 34.36 & 36.35 & 1.83 & 0.46 & 0.05 & 0.49 \\
\hline
\end{tabular}


Table 2. Cont

\begin{tabular}{|c|c|c|c|c|c|c|}
\hline \multirow{2}{*}{ Items } & \multicolumn{2}{|c|}{ Treatment } & \multirow{2}{*}{ SEM } & \multicolumn{3}{|c|}{$p$-Value } \\
\hline & $\mathrm{CON}$ & BET & & Treat & Week & Treat $\times$ Week \\
\hline $\mathrm{ECM}^{2}, \mathrm{~kg} / \mathrm{d}$ & 34.24 & 35.70 & 1.79 & 0.58 & 0.33 & 0.38 \\
\hline FE (FCM/DMI) & 1.80 & 2.00 & 0.08 & 0.09 & $<0.01$ & 0.22 \\
\hline FE (ECM/DMI) & 1.77 & 1.96 & 0.07 & 0.08 & $<0.01$ & 0.26 \\
\hline BW change, $\mathrm{kg} / \mathrm{d}$ & -1.18 & -1.51 & 0.13 & 0.10 & - & - \\
\hline
\end{tabular}

${ }^{1} 3.5 \%$ FCM $($ Fat-corrected milk $)=($ milk yield, $\mathrm{kg} / \mathrm{d} \times 0.4324)+($ milk fat, $\mathrm{kg} / \mathrm{d} \times 16.216)$ [20]. ${ }^{2} \mathrm{ECM}=($ milk yield, $\mathrm{kg} / \mathrm{d} \times 0.327)+($ milk fat, $\mathrm{kg} / \mathrm{d} \times 12.95)+($ milk protein, $\mathrm{kg} / \mathrm{d} \times 7.20)[20]$.

Table 3. Effects of supplementing cows without rumen-protected betaine (CON) or with rumen-protected betaine (BET) on blood metabolites from four weeks before expected calving to six weeks postpartum.

\begin{tabular}{|c|c|c|c|c|c|c|}
\hline \multirow{2}{*}{ Items ${ }^{1}$} & \multicolumn{2}{|c|}{ Treatment } & \multirow{2}{*}{ SEM } & \multicolumn{3}{|c|}{$p$-Value } \\
\hline & $\mathrm{CON}$ & BET & & Treat & Week & Treat $\times$ Week \\
\hline $\mathrm{TP}, \mathrm{g} / \mathrm{L}$ & 78.78 & 78.95 & 1.61 & 0.94 & $<0.01$ & 0.36 \\
\hline $\mathrm{ALB}, \mathrm{g} / \mathrm{L}$ & 25.77 & 25.42 & 0.35 & 0.50 & $<0.01$ & 0.28 \\
\hline GLOB, g/L & 53.01 & 53.53 & 2.02 & 0.86 & $<0.01$ & 0.56 \\
\hline $\mathrm{A} / \mathrm{G}$ & 0.50 & 0.49 & 0.02 & 0.76 & $<0.01$ & 0.76 \\
\hline ALT, U/L & 14.41 & 13.90 & 0.94 & 0.71 & $<0.01$ & 0.81 \\
\hline AST, U/L & 71.86 & 73.67 & 4.15 & 0.76 & $<0.01$ & 0.40 \\
\hline ALP, U/L & 33.29 & 36.34 & 1.81 & 0.26 & $<0.01$ & 0.91 \\
\hline TBIL, $\mu \mathrm{mol} / \mathrm{L}$ & 2.61 & 2.75 & 0.25 & 0.70 & $<0.01$ & 0.99 \\
\hline $\mathrm{TG}, \mathrm{mmol} / \mathrm{L}$ & 0.08 & 0.08 & 0.01 & 0.32 & $<0.01$ & 0.39 \\
\hline $\mathrm{CHOl}, \mathrm{mmol} / \mathrm{L}$ & 2.52 & 2.37 & 0.09 & 0.26 & $<0.01$ & 0.42 \\
\hline $\mathrm{GLU}, \mathrm{mmol} / \mathrm{L}$ & 3.34 & 3.30 & 0.07 & 0.72 & $<0.01$ & 0.83 \\
\hline $\mathrm{NEFA}, \mu \mathrm{mol} / \mathrm{L}$ & 246.57 & 243.90 & 20.74 & 0.93 & $<0.01$ & 0.95 \\
\hline $\mathrm{BHB}, \mu \mathrm{mol} / \mathrm{L}$ & 802.72 & 812.65 & 92.55 & 0.94 & $<0.01$ & 0.07 \\
\hline
\end{tabular}

${ }^{1} \mathrm{TP}=$ total protein. $\mathrm{ALB}=$ albumin. $\mathrm{GLOB}=$ globulin. $\mathrm{A} / \mathrm{G}=$ albumin/globulin. $\mathrm{ALT}=$ alanine aminotransferase. AST $=$ aspartate aminotransferase. $\mathrm{ALP}=$ alkaline phosphatase. TBIL $=$ total bilirubin. $\mathrm{TG}=$ triglyceride. $\mathrm{CHOL}=$ cholesterol. $\mathrm{GLU}=$ glucose. NEFA $=$ non-esterified fatty acids. $\mathrm{BHB}=\beta$-hydroxybutyrate.

The plasma TP and GLOB concentrations of the BET calves were greater than those of the CON calves $(p=0.04, p=0.05$, respectively, Table 4$)$, although no differences in calves birth weight were found between treatments $(37.80 \pm 1.68 \mathrm{~kg}$ vs. $36.03 \pm 1.68 \mathrm{~kg})$. The plasma TP and GLOB concentrations of calves increased significantly with maternal betaine supplementation, which indicates that it might improve the immunity of newborn calves because of maternal methyl donors supplementation $[13,27]$. Maternal dietary supplementation with methyl donors could program the health of offspring through the epigenetic regulation of the DNA molecule and cell signaling $[27,28]$, which might improve the capacity for GLOB absorption of the intestine to improve the immunity of newborn calves. Furthermore, the lactose content of the BET colostrum tended to increase compared to the CON colostrum in our study $(3.50 \%$ vs. $3.07 \%, p=0.07)$, which might also have contributed to the results. Lactose plays a key role in the energy supply, absorption of minerals, and gastrointestinal functions of calves $[29,30]$.

The plasma GLU concentrations of the BET calves tended to decrease compared with those of the CON calves ( $p=0.09$, Table 4 ). The plasma SOD concentrations of the BET calves were greater at $2 \mathrm{~h}$ after birth than those of the CON cows (treatment $\times$ time: $p=0.01$, Table 4). A positive correlation between neonatal glucose and cortisol concentrations proved that the lower concentrations of glucose in the BET calves were likely to have less stress around calving [31]. In turn, the degree of stress might influence newborn calves' energetic mobilization [31,32]. The greater plasma SOD concentrations $2 \mathrm{~h}$ after birth in our study suggested that the BET calves were in a state of less stress [33]. The plasma glucose concentrations in newborn calves might be related to the uteroplacental transport of glucose via mTOR signaling [34] and hepatic gluconeogenic gene expression via epigenetic mechanisms [35], which deserve further study. 
Table 4. The blood metabolites during the $24 \mathrm{~h}$ after birth of calves born to dams supplemented without rumen-protected betaine $(\mathrm{CON})$ or with rumen-protected betaine (BET) during the peripartal period.

\begin{tabular}{|c|c|c|c|c|c|c|}
\hline \multirow{2}{*}{ Items ${ }^{1}$} & \multicolumn{2}{|c|}{ Treatment } & \multirow{2}{*}{ SEM } & \multicolumn{3}{|c|}{$p$-Value } \\
\hline & CON Calves & BET Calves & & Treat & Hour & Treat $\times$ Hour \\
\hline $\mathrm{TP}, \mathrm{g} / \mathrm{L}$ & 54.71 & 59.63 & 1.48 & 0.04 & $<0.01$ & 0.15 \\
\hline $\mathrm{ALB}, \mathrm{g} / \mathrm{L}$ & 18.48 & 18.59 & 0.42 & 0.85 & 0.00 & 0.03 \\
\hline GLOB, g/L & 36.23 & 41.03 & 1.57 & 0.05 & $<0.01$ & 0.06 \\
\hline $\mathrm{A} / \mathrm{G}$ & 0.58 & 0.56 & 0.02 & 0.54 & $<0.01$ & 0.04 \\
\hline ALT, U/L & 7.67 & 8.24 & 0.37 & 0.30 & $<0.01$ & 0.21 \\
\hline AST, U/L & 53.67 & 55.31 & 4.98 & 0.82 & $<0.01$ & 0.87 \\
\hline ALP, U/L & 265.38 & 257.78 & 35.73 & 0.88 & $<0.01$ & 0.86 \\
\hline $\mathrm{TBIL}, \mu \mathrm{mol} / \mathrm{L}$ & 6.21 & 6.60 & 0.87 & 0.76 & 0.05 & 0.97 \\
\hline GLU, mmol/L & 5.62 & 4.82 & 0.30 & 0.09 & 0.00 & 0.36 \\
\hline $\mathrm{SOD}, \mathrm{U} / \mathrm{ml}$ & 66.54 & 70.52 & 2.91 & 0.35 & 0.00 & 0.01 \\
\hline
\end{tabular}

${ }^{1} \mathrm{TP}=$ total protein. $\mathrm{ALB}=$ albumin. $\mathrm{GLOB}=$ globulin. $\mathrm{A} / \mathrm{G}=$ albumin/globulin. $\mathrm{ALT}=$ alanine aminotransferase. $\mathrm{AST}=$ aspartate aminotransferase. $\mathrm{ALP}=$ alkaline phosphatase. $\mathrm{TBIL}=$ total bilirubin. $\mathrm{GLU}=$ glucose. $\mathrm{SOD}=$ superoxide dismutase.

\section{Conclusions}

Dietary rumen-protected betaine supplementation from four weeks before expected calving had no detectable effect on dry matter intake and milk yield, but tended to increase fat mobilization of postpartum dairy cows. Furthermore, the BET calves had greater plasma total protein and globulin concentrations, which indicates that the immunity of the BET calves might improve.

Author Contributions: Conceived and designed the experiments: B.W., C.W., J.L. and H.L. Conducted the experimental work: B.W., R.G. and K.S. Conducted the data analysis: B.W. and Z.W. Wrote the paper: B.W. Revised the paper: B.W., C.W. and H.L.

Funding: Grants from the National Key Research and Development Program of China (2018YFD0501600), the China Agriculture Research System (No. CARS-37), and the Zhejiang Provincial Natural Science Foundation (LY18C170002) supported this research.

Acknowledgments: The authors thank Hangjiang Dairy Farm (Hangzhou, China) for providing and caring for the cows.

Conflicts of Interest: The authors declare no conflict of interest.

\section{References}

1. Coonen, J.M.; Maroney, M.J.; Crump, P.M.; Grummer, R.R. Short communication: Effect of a stable pen management strategy for precalving cows on dry matter intake, plasma nonesterified fatty acid levels, and milk production. J. Dairy Sci. 2011, 94, 2413-2417. [CrossRef] [PubMed]

2. Zhou, Z.; Vailati-Riboni, M.; Luchini, D.N.; Loor, J.J. Methionine and choline supply during the periparturient period alter plasma amino acid and one-carbon metabolism profiles to various extents: Potential role in hepatic metabolism and antioxidant status. Nutrients 2017, 9, 10. [CrossRef] [PubMed]

3. Pinotti, L.; Baldi, A.; Dell'Orto, V. Comparative mammalian choline metabolism with emphasis on the high-yielding dairy cow. Nutr. Res. Rev. 2002, 15, 315-332. [CrossRef]

4. Bauman, D.E.; Currie, W.B. Partitioning of nutrients during pregnancy and lactation: A review of mechanisms involving homeostasis and homeorhesis. J. Dairy Sci. 1980, 63, 1514-1529. [CrossRef]

5. Engin, F.; Hotamisligil, G.S. Restoring endoplasmic reticulum function by chemical chaperones: An emerging therapeutic approach for metabolic diseases. Diabetes Obes. Metab. 2010, 12, 108-115. [CrossRef] [PubMed]

6. Eklund, M.; Bauer, E.; Wamatu, J.; Mosenthin, R. Potential nutritional and physiological functions of betaine in livestock. Nutr. Res. Rev. 2005, 18, 31-48. [CrossRef]

7. Pas, B.J.B.; Pas, J.R.B.; Harmoney, K.R.; Pas, S.R.G. Influence of betaine on pasture, finishing, and carcass performance in steers. Prof. Anim. Sci. 2004, 20, 53-57. 
8. Peterson, S.E.; Rezamand, P.; Williams, J.E.; Price, W.; Chahine, M.; Mcguire, M.A. Effects of dietary betaine on milk yield and milk composition of mid-lactation Holstein dairy cows. J. Dairy Sci. 2012, 95, 6557-6562. [CrossRef] [PubMed]

9. Zhang, L.; Ying, S.J.; An, W.J.; Lian, H.; Zhou, G.B.; Han, Z.Y. Effects of dietary betaine supplementation subjected to heat stress on milk performances and physiology indices in dairy cow. Genet. Mol. Res. 2014, 13, 7577-7586. [CrossRef]

10. Wang, C.; Liu, Q.; Yang, W.Z.; Wu, J.; Zhang, W.W.; Zhang, P.; Dong, K.H.; Huang, Y.X. Effects of betaine supplementation on rumen fermentation, lactation performance, feed digestibilities and plasma characteristics in dairy cows. J. Agric. Sci. 2010, 148, 487-495. [CrossRef]

11. Monteiro, A.P.A.; Bernard, J.K.; Guo, J.R.; Weng, X.S.; Emanuele, S.; Davis, R.; Dahl, G.E.; Tao, S. Effects of feeding betaine-containing liquid supplement to transition dairy cows. J. Dairy Sci. 2017, 100, 1063-1071. [CrossRef]

12. Lever, M.; Slow, S. The clinical significance of betaine, an osmolyte with a key role in methyl group metabolism. Clin. Biochem. 2010, 43, 732-744. [CrossRef] [PubMed]

13. Van, L.L.; Tint, M.T.; Aris, I.M.; Quah, P.L.; Fortier, M.V.; Lee, Y.S.; Yap, F.K.; Saw, S.M.; Godfrey, K.M.; Gluckman, P.D. Prospective associations of maternal betaine status with offspring weight and body composition at birth: The GUSTO (Growing Up in Singapore Toward healthy Outcomes) cohort study. Am. J. Clin. Nutr. 2016, 104, 1327-1333. [CrossRef]

14. Mitchell, A.D.; Chappell, A.; Knox, K.L. Metabolism of betaine in the ruminant. J. Anim. Sci. 1979, 49, 764-774. [CrossRef]

15. Liu, H. Effects of Dietary Supplementation of Rumen-Protected Betaine on Lactation Performance and Serum Metabolites of Dairy Cows. Master's Thesis, Zhejiang University, Hangzhou, China, 2017.

16. NRC. Nutrient Requirements of Dairy Cattle, 7th ed.; National Academy Press: Washington, DC, USA, 2001.

17. Gu, F.F.; Liang, S.L.; Wei, Z.H.; Wang, C.P.; Liu, H.Y.; Liu, J.X.; Wang, D.M. Short communication: Effects of dietary addition of $\mathrm{N}$-carbamylglutamate on milk composition in mid-lactating dairy cows. J. Dairy Sci. 2018, 101, 10985-10990. [CrossRef] [PubMed]

18. Van Soest, P.J.; Robertson, J.B.; Lewis, B.A. Methods for dietary fiber, neutral detergent fiber, and nonstarch polysaccharides in relation to animal nutrition. J. Dairy Sci. 1991, 74, 3583-3597. [CrossRef]

19. Wang, D.M.; Zhang, B.X.; Wang, J.K.; Liu, H.Y.; Liu, J.X. Short communication: Effects of dietary 5,6-dimethylbenzimidazole supplementation on vitamin B 12 supply, lactation performance, and energy balance in dairy cows during the transition period and early lactation. J. Dairy Sci. 2017, 101, 1-4.

20. Tyrrell, H.F.; Reid, J.T. Prediction of the energy value of cow's milk. J. Dairy Sci. 1965, 48, 1215-1223. [CrossRef]

21. Fouché, N.; Graubner, C.; Howard, J. Correlation between serum total globulins and gamma globulins and their use to diagnose failure of passive transfer in foals. Vet. J. 2014, 202, 384-386. [CrossRef]

22. Ratriyanto, A.; Mosenthin, R.; Bauer, E.; Eklund, M. Metabolic, osmoregulatory and nutritional functions of betaine in monogastric animals. Asian-Australas. J. Anim. Sci. 2009, 22, 1461-1476. [CrossRef]

23. Bernier-Dodier, P.; Girard, C.L.; Talbot, B.G.; Lacasse, P. Effect of dry period management on mammary gland function and its endocrine regulation in dairy cows. J. Dairy Sci. 2011, 94, 4922-4936. [CrossRef] [PubMed]

24. Wang, C.; Liu, H.Y.; Wang, Y.M.; Yang, Z.Q.; Liu, J.X.; Wu, Y.M.; Yan, T.; Ye, H.W. Effects of dietary supplementation of methionine and lysine on milk production and nitrogen utilization in dairy cows. J. Dairy Sci. 2010, 93, 3661-3670. [CrossRef] [PubMed]

25. Zhou, Z.; Vailati-Riboni, M.; Trevisi, E.; Drackley, J.K.; Luchini, D.N.; Loor, J.J. Better postpartal performance in dairy cows supplemented with rumen-protected methionine compared with choline during the peripartal period. J. Dairy Sci. 2016, 99, 8716-8732. [CrossRef] [PubMed]

26. Dann, H.M.; Litherland, N.B.; Underwood, J.P.; Bionaz, M.; D’Angelo, A.; Mcfadden, J.W.; Drackley, J.K. Diets during far-off and close-up dry periods affect periparturient metabolism and lactation in multiparous cows. J. Dairy Sci. 2006, 89, 3563-3577. [CrossRef]

27. Liu, J.; Yao, Y.; Yu, B.; Mao, X.; Huang, Z.; Chen, D. Effect of maternal folic acid supplementation on hepatic proteome in newborn piglets. Nutrition 2013, 29, 230-234. [CrossRef] [PubMed]

28. Ji, Y.; Wu, Z.; Dai, Z.; Sun, K.; Wang, J.; Wu, G. Nutritional epigenetics with a focus on amino acids: Implications for the development and treatment of metabolic syndrome. J. Nutr. Biochem. 2016, 27, 1-8. [CrossRef] [PubMed] 
29. Frizzo, L.S.; Soto, L.P.; Zbrun, M.V.; Signorini, M.L. Effect of lactic acid bacteria and lactose on growth performance and intestinal microbial balance of artificially reared calves. Livest. Sci. 2011, 140, $246-252$. [CrossRef]

30. Liu, J.; Chang, J.; Yao, A.; Hu, Y.; Yuan, Y.; Yu, F.; Ma, Z.; Wang, G.; Zhao, X. Diagnosis and clinical observation of lactose-free milk powder on treatment of neonatal diarrhea. Pak. J. Pharm. Sci. 2016, 29, 309-314. [PubMed]

31. Vannucchi, C.I.; Rodrigues, J.A.; Silva, L.C.G.; Lúcio, C.F.; Veiga, G.A.L.; Furtado, P.V.; Oliveira, C.A.; Nichi, M. Association between birth conditions and glucose and cortisol profiles of periparturient dairy cows and neonatal calves. Vet. Rec. 2015, 176, 358. [CrossRef]

32. Jacometo, C.B.; Zhou, Z.; Luchini, D.; Trevisi, E.; Corrêa, M.N.; Loor, J.J. Maternal rumen-protected methionine supplementation and its effect on blood and liver biomarkers of energy metabolism, inflammation, and oxidative stress in neonatal Holstein calves. J. Dairy Sci. 2016, 99, 6753-6763. [CrossRef] [PubMed]

33. Hassanpour, A.; Sabegh, Y.G.; Sadeghi-nasab, A. Assessment of serum antioxidant enzymes activity in cattle suffering from Theileriosis. Eur. J. Exp. Biol. 2013, 3, 493-496.

34. Batistel, F.; Alharthi, A.S.; Wang, L.; Parys, C.; Pan, Y.X.; Cardoso, F.C.; Loor, J.J. Placentome nutrient transporters and mammalian target of rapamycin signaling proteins are altered by the methionine supply during late gestation in dairy cows and are associated with newborn birth weight. J. Nutr. 2017, 147, 1640-1647. [CrossRef]

35. Cai, D.; Jia, Y.; Song, H.; Sui, S.; Lu, J.; Jiang, Z.; Zhao, R. Betaine supplementation in maternal diet modulates the epigenetic regulation of hepatic gluconeogenic genes in neonatal piglets. PLoS ONE 2013, 9, e105504. [CrossRef]

(C) 2019 by the authors. Licensee MDPI, Basel, Switzerland. This article is an open access article distributed under the terms and conditions of the Creative Commons Attribution (CC BY) license (http://creativecommons.org/licenses/by/4.0/). 